\title{
KETAHANAN ENAM KLON KARET TERHADAP INFEKSI CORYNESPORA CASSIICOLA PENYEBAB PENYAKIT GUGUR DAUN
}

\author{
Nurhayati $^{1}$, Fatma $^{1}$ \& M. Idrus Aminuddin ${ }^{1}$
}

\begin{abstract}
Resistance of six rubber clones to Corynespora cassiicola the pathogen of rubber leaffall disease. The objectives of the research was to evaluate the resistance of six rubber clones to Corynespora cassiicola, the pathogen of rubber leaf fall disease. The research was conducted at Phytophatology laboratorium and green house at the Plant Pest and Diseases Department, Faculty of Agriculture, Sriwijaya University, from March to July 2008. The treatments were arranged in a completely randomized block design (CRBD) with six treatments and four replications. Each replication consisted of four polibags of rubber plants. The clons tested were GT 1, PB 260, IRR 39, BPM 1, BPM 24 and PR 261. The results showed that IRR 39 was the most susceptible clon to $C$. cassiicola infection, whereas disease severety reach up to $98.45 \%$ and leaf fall $73.95 \%$. Clon PB 260 show as the moderat resistance clon to the pathogen infection. The severity disease of this clon only $41.53 \%$ and leaf fall $10.41 \%$.
\end{abstract}

Key words: clons resistance, Corynespora cassiicola, rubber leaf fall disease

\section{PENDAHULUAN}

Luas perkebunan karet di Indonesia sekitar 3,6 juta hektar yang meliputi $80 \%$ perkebunan karet rakyat serta $20 \%$ perkebunan negara dan atau swasta. Perkebunan karet di Indonesia terluas terdapat di Pulau Sumatera yaitu sebesar 70\%, diikuti Kalimantan (20\%), Jawa (5\%) dan lainnya (5\%). Luas perkebunan karet di Provinsi Sumatera Selatan tiap tahun terus meningkat baik yang dikelola oleh perkebunan negara dan atau swasta maupun yang diusahakan oleh rakyat. Luas areal perkebunan karet di Sumatera Selatan saat ini tercatat 850.000 hektar (Direktorat Jendral Perkebunan, 1996; 1998; Statistik Perkebunan Indonesia, 2004).

Nilai ekspor karet Indonesia, seperti dilaporkan oleh Biro Pusat Statistik, meningkat 30,98\% dari US \$ 2,23 miliar pada 2003 menjadi US \$2,92 miliar pada 2004. Berdasarkan perhitungan Gabungan Perusahaan Karet Indonesia, volume ekspor komoditas tersebut meningkat dari 1,66 juta ton pada 2003 menjadi 1,88 juta ton pada 2004 (Tempointeraktif, 2005).

Namun demikian produktivitas karet di Indonesia tergolong relatif rendah. Perkebunan negara produktivitasnya rata-rata hanya sekitar $1260 \mathrm{~kg}$ per hektar per tahun, sedangkan perkebunan swasta 1050 kg per hektar per tahun dan perkebunan rakyat hanya $590 \mathrm{~kg}$ per hektar per tahun. Salah satu penyebab rendahnya produktivitas karet tersebut karena adanya gangguan penyakit (Suhendry \& Alwi, 1990).

Penyakit gugur daun Corynespora (PGDC) yang disebabkan oleh Corynespora cassiicola merupakan salah satu penyakit karet yang sangat penting. Hal ini karena penyakit ini dapat mengakibatkan peranggasan tanaman karet sepanjang tahun sehingga pertumbuhan terhambat, penyadapan tidak dapat dilakukan dan bahkan menyebabkan kematian tanaman. Selain menyerang tanaman di lapangan penyakit ini juga menjangkiti tanaman karet yang ada di pembibitan, sehingga dapat mengakibatkan kerugian yang besar. Penyakit ini dapat menyerang daun karet baik yang masih muda maupun yang telah tua (Situmorang \& Budiman, 1984).

Menurut Soepena (1986) dan Pawirosoemardjo (2004) serangan C. cassiicola sangat berpengaruh terhadap pertumbuhan tanaman muda sehingga masa matang sadap terhambat atau diperpanjang 3 sampai 5 tahun atau lebih, atau sama sekali gagal untuk matang sadap. Pada klon GT 1 yang terserang gugur daun selama dua bulan dapat menurunkan produksi getah lebih dari $40 \%$ dari produksi normal. Serangan berat gugur daun pada tanaman karet klon PPN 2058 dan PPN 2447

\footnotetext{
1 Jurusan Hama dan Penyakit Tumbuhan, Fakultas Pertanian, Universitas Sriwijaya,

Kampus Unsri Indralaya, J1. Raya Prabumulih Ogan Ilir 30662, Sumatera Selatan. E-mail: nurhayatidamiri@yahoo.co.id
} 
di Jawa Tengah mengakibatkan penurunan produksi lateks antara 24 dan 62\% (Pusat Penelitian dan Pengembangan Perkebunan Tanjung Morawa, 1988).

Penyakit ini semakin penting ketika beberapa klon sebelumnya bersifat tahan dan moderat dilaporkan telah mengalami pergeseran ketahanan menjadi rentan dan terserang hebat setelah beberapa tahun kemudian (Toruan-Mahius et al., 2002). Terjadinya pergeseran ketahanan ini, telah dibuktikan oleh kenyataan dengan klon RRIM yang pada tahun 80-an merupakan klon yang tahan terhadap patogen tersebut kini telah menjadi klon yang rentan dan tidak dianjurkan lagi. Di Sumatera selatan klon BPM 24 dan klon PR 261 sampai tahun 2004 masih tergolong klon resisten terhadap gugur daun corynespora (Situmorang, 2002; Situmorang et al., 2004).

Pergeseran ketahanan pada klon-klon karet antara lain disebabkan C. cassiicola merupakan jamur patogen yang mempunyai patogenitas tinggi dan mampu menyesuaikan diri terhadap lingkungannya dengan cepat sehingga dikhawatirkan klon-klon yang semula tahan akhirnya terserang juga (Soepena, 1983).

Klon-klon karet yang ada di Indonesia bahkan di Asia berasal dari pohon-pohon induk dengan sifatsifatnya yang tidak jauh berbeda. Oleh karena itu ketahanannya terhadap penyakit tidak jauh berbeda. Perbedaan ketahanan terhadap $C$. cassiicola yang tampak sekarang hanya bersifat semu, yang pada akhirnya suatu saat nanti akan muncul sifat peka terhadap penyakit gugur daun tersebut (Situmorang, 2002).

Penelitian ini bertujuan untuk mengevaluasi ketahanan klon-klon karet yang banyak dibudidayakan para petani karet di Sumatera Selatan terhadap infeksi C. cassiicola penyebab penyakit gugur daun Corynespora.

\section{METODE PENELITIAN}

Penelitian ini dilakukan di laboratorium dan rumah kaca Jurusan Hama dan Penyakit Tumbuhan, Fakultas Pertanian, Universitas Sriwijaya dari Maret sampai dengan Juli 2008. Penelitian dilaksanakan dengan menggunakan rancangan acak kelompok (RAK) dengan enam perlakuan dan empat ulangan. Tiap ulangan terdiri dari empat pot tanaman karet. Perlakuan yang diujikan adalah enam klon karet yaitu: GT1, PB 260, IRR 39, BPM 1, BPM 24 dan PR 261.

Dalam penelitian ini digunakan konidia sebagai inokulum. Produksi konidia dilakukan secara massal dengan membiarkannya terlebih dahulu biakan murni
C. cassiicola selama 4 sampai 7 hari pada media ASK (agar sukrosa kentang: $200 \mathrm{~g}$ kentang, $30 \mathrm{~g}$ sukrosa dan $15 \mathrm{~g}$ agar dalam satu liter air destilasi) dalam cawan petri. Selanjutnya sebanyak 8-10 potongan $(\varnothing 5 \mathrm{~mm})$ biakan diletakkan dengan posisi terbalik pada permukaan bawah daun karet steril dalam cawan petri sehingga miselia kontak langsung ke permukaan daun. Daun yang digunakan adalah yang berwarna hijau muda yang disterilisasi terlebih dahulu dengan otoklaf pada suhu $110^{\circ} \mathrm{C}$. Setelah 3-4 hari masa inkubasi, posisi daun dibalik. Konidia yang terbentuk pada daun tersebut digunakan untuk inokulasi dalam percobaan ini.

Daun yang telah berkonidia selanjutnya dikeringanginkan pada suhu kamar selama satu hari agar pelepasan konidia lebih muda dilakukan. Konidia selanjutnya disapu dengan kuas dan dimasukkan ke dalam labu erlenmeyer yang telah berisi air steril dan selanjutnya disaring dengan kasa nilon untuk memisahkan konidia yang menggumpal. Konsentrasi konidia dihitung sebanyak $4 \times 10^{4}$ menggunakan haemocytometer.

Penyemprotan inokulum dilakukan menggunakan jet sprayer pada permukaan bawah daun sesuai dengan masing-masing perlakuan sebanyak tiga kali semprot. Selanjutnya daun disungkup dengan plastik transparan $(10 \mathrm{x} 15 \mathrm{~cm})$ untuk mempertahankan kelembaban selama masa inkubasi. Setelah 3 hari plastik sungkup diangkat.

Parameter yang diamati adalah masa inkubasi, keparahan penyakit dan jumlah daun yang gugur. Keparahan penyakit diamati satu minggu sekali, setelah inokulasi, sedangkan jumlah daun gugur dihitung di akhir penelitian. Penghitungan keparahan penyakit berdasarkan skala serangan pada daun sebagai berikut: 1) 0 = tidak ada serangan, 2) $1=$ ada gejala bercak cokelat kehitaman, 3) $2=>1-50 \%$ daun kuning kecokelatan, 4) $3=>50-100 \%$ daun kuning kecokelatan dan gugur. Selanjutnya hasil penilaian skala serangan tersebut dimasukkan dalam rumus :

$$
I=\frac{\sum\left(n_{i} x_{j}\right)}{(N x V)} \times 100 \%
$$

dimana:

$\mathrm{I}=$ persentase keparahan penyakit

$\mathrm{n}=$ jumlah pengamatan ke-i pada tingkat serangan

(v) ke-j

$\mathrm{N}=$ jumlah seluruh pengamatan

$\mathrm{V}=$ tingkat serangan tertinggi 
Berdasarkan hasil perhitungan keparahan penyakit ketahanan klon dibagi 4 kelompok: $0 \%=$ klon sangat resisten; $>0-45 \%=$ serangan ringan $/$ moderat resisten; > 45-67\% = serangan agak berat $/$ moderat rentan dan $68-100 \%=$ klon rentan.

Data yang diperoleh dalam percobaan ini dianalisis dengan menggunakan sidik ragam yang dilanjutkan Uji Beda Nyata Terkecil.

\section{HASIL DAN PEMBAHASAN}

Masa Inkubasi dan Gejala. Hasil pengamatan terhadap semua perlakuan menunjukkan rata-rata masa inkubasi adalah 3 hari setelah inokulasi. Gejala yang muncul pertama kali pada daun muda berupa bercak kecil berwarna hitam yang terdapat pada tulang atau urat daun. Gejala selanjutnya berupa bercak yang berkembang mengikuti tulang daun sehingga mirip seperti tulang ikan, terjadi 8 hari setelah inokulasi. Pada tingkat serangan lebih lanjut bercak semakin meluas dengan daun-daun berwarna kuning dan kemudian gugur.

Keparahan Penyakit. Hasil sidik ragam menunjukkan bahwa perlakuan inokulasi $C$. cassiicola pada enam klon karet berpengaruh nyata terhadap keparahan penyakit gugur daun Corynespora. Hasil uji BNT terhadap pengaruh infeksi $C$. cassiicola pada enam klon karet disajikan pada Tabel 1. Pada minggu pertama, klon BPM 1 merupakan klon yang paling parah terserang C. cassiicola dengan persentase keparahan penyakit 42,65\%. Keparahan penyakit pada klon BPM 1 ini tidak berbeda nyata dengan yang terjadi pada klon GT1, IRR 36, BPM24 dan PR 261 tetapi berbeda nyata dengan kaparahan penyakit pada klon PB 260. Klon PB 260 merupakan klon karet yang sampai saat ini disebut moderat resisten dengan persentase serangan penyakit $26,77 \%$.

Tabel 1 menunjukkan pada minggu kedua, ketiga dan keempat setelah inokulasi, ternyata klon karet yang rentan terhadap infeksi patogen gugur daun Corynespora adalah klon IRR 39, diikuti klon GT1, BPM 24 dan PR 261 yang pada pengamatan terakhir menunjukkan perbedaan yang nyata dengan klon BPM 1 dan PR 260. Perkembangan penyakit pada keenam klon tersebut dapat dilihat pada Gambar 1.

Jumlah Daun yang Gugur. Pengaruh inokulasi C. cassiicola terhadap jumlah daun yang gugur pada keenam klon karet disajikan pada Tabel 2.

Dari Tabel 2 terlihat bahwa klon yang paling banyak mengalami gugur daun akibat serangan C. cassiicola adalah klon IRR 39, walaupun persentase gugur daun ini tidak berbeda nyata dengan perlakuan klon GT 1, BPM 24 dan PR 261 tetapi berbeda nyata dengan perlakuan klon BPM 1 dan PB 260. Persentase gugur daun akibat $C$. cassiicola yang dialami klon IRR 39 mencapai $73,95 \%$ sedangkan pada klon PB 260 hanya $10,41 \%$.

Klon IRR 39, GT1, BPM 24 dan PR 261 merupakan klon yang rentan terhadap gugur daun Corynespora. Diduga bahwa klon-klon yang diujikan tersebut tidak mampu menekan atau membatasi perkembangan jamur $C$. cassiicola, karena jamur

Tabel 1. Pengaruh infeksi $C$. cassiicola terhadap perkembangan keparahan penyakit gugur daun Corynespora pada enam klon karet

\begin{tabular}{ccccc}
\hline \multirow{2}{*}{ Klon karet } & \multicolumn{5}{c}{ Persentase keparahan penyakit (\%) } \\
\cline { 2 - 5 } & 1 MSI & 2 MSI & 3 MSI & 4 MSI \\
\hline IRR 39 & $42,65 \mathrm{a}$ & $95,55 \mathrm{a}$ & $98,15 \mathrm{a}$ & $98,45 \mathrm{a}$ \\
GT 1 & $40,57 \mathrm{a}$ & $74,30 \mathrm{~b}$ & $77,30 \mathrm{ab}$ & $78,68 \mathrm{ab}$ \\
BPM 24 & $36,17 \mathrm{ab}$ & $72,02 \mathrm{~b}$ & $76,78 \mathrm{ab}$ & $76,78 \mathrm{ab}$ \\
PR 261 & $35,15 \mathrm{ab}$ & $67,70 \mathrm{~b}$ & $70,30 \mathrm{bc}$ & $72,80 \mathrm{~b}$ \\
BPM 1 & $43,90 \mathrm{a}$ & $40,07 \mathrm{c}$ & $47,10 \mathrm{~cd}$ & $47,88 \mathrm{c}$ \\
PB 260 & $26,77 \mathrm{~b}$ & $38,52 \mathrm{c}$ & $41,10 \mathrm{~d}$ & $41,53 \mathrm{c}$ \\
\hline
\end{tabular}

Keterangan: Angka-angka yang diikuti oleh huruf yang sama pada kolom yang sama berarti tidak berbeda nyata pada taraf $5 \%$ menurut Uji Beda Nyata Terkecil.

MSI: minggu setelah inokulasi. 
tersebut mampu menghasilkan toksin yang dapat mempercepat kerusakan jaringan daun karet. Disamping itu diduga isolat yang digunakan merupakan isolat yang mempunyai virulensi yang tinggi, karena berasal dari jamur C. cassiicola yang menyerang karet klon GT 1 . Menurut Pawirosoemardjo (2004) dan Situmorang (2002), bahwa C . cassiicola mampu menghasilkan toksin yang mampu mempercepat kerusakan dan mendorong gugurnya daun. Situmorang (2002) menandaskan bahwa isolat yang berasal dari klon GT 1 merupakan isolat yang mempunyai toksisitas dan efisiensi infeksi tinggi sehingga mampu merusak jaringan tanaman dengan cepat. Berdasarkan penelitian ini terlihat juga bahwa klon BPM 24 dan klon PR 261 yang semula termasuk klon yang resisten atau tahan terhadap infeksi $C$. cassiicola ternyata mengalami pergeseran ketahanan menjadi rentan. Terjadinya pergeseran ketahanan ini diduga karena klon-klon yang ada di Indonesia bahkan Asia berasal dari pohon-pohon induk dimana sifat-sifatnya tidak jauh berbeda. Oleh karenanya ketahanan terhadap penyakit juga tidak jauh berbeda. Perbedaan ketahanan yang ada hanya bersifat semu, yang akhirnya pada suatu saat muncul kembali sifat peka terhadap patogen (Soepena, 1983). Di samping itu $C$. cassiicola mempunyai kemampuan yang tinggi untuk menyesuaikan diri terhadap lingkungan sehingga dapat mematahkan ketahanan klon-klon yang semula tahan. Sampai saat ini klon PB 260 dan BPM 1 masih menunjukkan keresistenan terhadap infeksi C. cassiicola, namun demikian pemantaun yang kontinyu harus tetap dilakukan, karena dikhawatirkan akan terjadi pergeseran ketahanan di waktu yang akan datang.

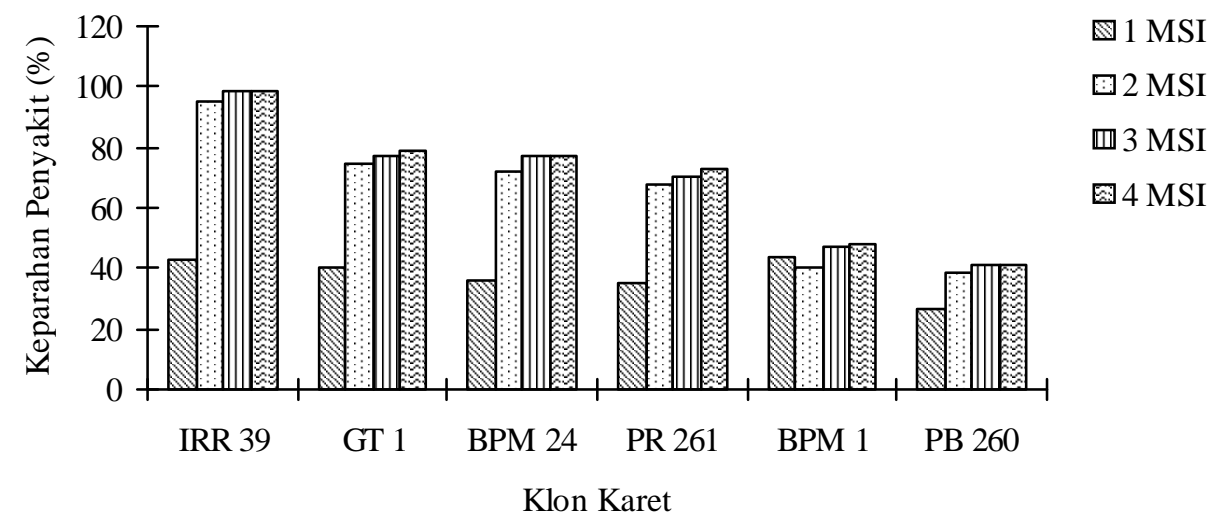

Gambar 1. Perkembangan penyakit gugur daun corynespora pada enam klon karet

Tabel 2. Pengaruh infeksi $C$. cassiicola terhadap jumlah daun yang gugur pada enam klon karet

\begin{tabular}{cc}
\hline Klon Karet & Daun yang gugur $(\%)$ \\
\hline IRR 39 & $73,95 \mathrm{a}$ \\
GT 1 & $70,80 \mathrm{a}$ \\
BPM 24 & $64,58 \mathrm{ab}$ \\
PR 261 & $56,25 \mathrm{abc}$ \\
BPM 1 & $20,83 \mathrm{bc}$ \\
PB 260 & $10,41 \mathrm{c}$ \\
\hline
\end{tabular}

Keterangan: Angka-angka yang diikuti oleh huruf yang sama pada kolom yang sama berarti tidak berbeda nyata pada taraf $5 \%$ menurut Uju Beda Nyata Terkecil. 


\section{SIMPULAN}

Penelitian ini menyimpulkan sebagai berikut:

1. Klon yang moderat resisten terhadap infeksi $C$. cassiicola adalah PB 260, dengan nilai keparahan penyakit dan persentase daun gugur berturut-turut $41,53 \%$ dan $10,41 \%$.

2. Klon yang tergolong rentan adalah: IRR 39, GT 1, BPM 24, dan PR 261.

\section{DAFTAR PUSTAKA}

Direktorat Jendral Perkebunan. 1996. Statistik Perkebunan Indonesia. Direktorat Jendral Perkebunan, Jakarta.

Direktorat Jendral Perkebunan. 1998. Statistik Perkebunan Indonesia. Direktorat Jendral Perkebunan, Jakarta.

Pawirosoemardjo S. 2004. Manajemen pengendalian penyakit penting dalam upaya mengamankan target produksi karet nasional tahun 2020. Proc. Pertemuan teknis. Pusat Penelitian Karet Balai Penelitian Sembawa.

Pusat Penelitian dan Pengembangan Perkebunan Tanjung Morawa (P4TM). 1988. Forum Komunikasi Perkebunan. Balai Penelitian. PT Perkebunan Wilayah II. Sungai karang 25 Januari 1988.

Situmorang A \& Budiman A. 1984. Corynespora cassiicola (Berk \& Curt) Wei penyebab penyakit gugur daun pada karet. Kumpulan makalah lokakarya karet 1984, PN/PT Perkebunan Wilayah-1 dan P4TM, 14-16 Nopember 1984 di Medan. P4TM.

Situmorang A. 2002. Sebaran penyakit gugur daun, virulensi dan genetika Corynespora cassiicola asal sentra perkebunan karet Indonesia. Disertasi. Program Pascasarjana. Institut Pertanian Bogor.
Situmorang A, Sinaga MS, Suseno R, Hidayat SH, Siswanto \& Darusamin A. 2004. Status dan managemen pengendalian penyakit gugur daun corynespora di perkebunan karet. Proc. Pertemuan teknis. Pusat Penelitian Karet Balai Penelitian Sembawa.

Soepena H. 1983. Gugur daun corynespora pada tanaman karet di Sumatera Utara. Balai Penelitian Perkebunan Sei Putih.

Soepena H. 1986. Penyakit gugur daun Corynespora pada tanaman karet. Pertemuan Karet dan Kelapa. Semarang 6-7 Februari 1986. Research Centre Getas. PN/PT Perkebunan Salatiga.

Statistik Perkebunan Indonesia. 2004. Profil Karet (Hevea brasiliensis) (On line). www.agribisdeptan.go.id/kebun/komoditas/karet/ prokaret. Diakses pada tanggal 5 April 2006.

Suhendry I \& Alwi N. 1990. Produktivitas kebun dan trend produksi klon. Makalah pada konfrensi nasional karet di Palembang. 18-20 September 1990.

Tempointeraktif. 2005. Vietnam diminta ikut kendalikan harga karet. www.tempointeractiqve.com/hg/ ekbis. Diakses pada tanggal 5 April 2006

Toruan-Mahius N, Lalu Z, Soedarsono \& Aswidinnoor H. 2002. Keragaman genetik klon-klon karet (Hevea brasiliensis Muell. Arg) yang resisten dan rentan terhadap Corynespora cassiicola berdasarkan penanda RAPD dan AFLP. Menara Perkebunan 70(2): 35-49. 